\title{
Identification and Characterization of a Monocyte-derived Neutrophil-activating Factor in Corticosteroid-resistant Bronchial Asthma
}

\author{
James R. W. Wilkinson, ${ }^{\star \star}$ Attilio E. G. Crea, ${ }^{\star}$ Tim J. H. Clark, ${ }^{\star}$ and Tak H. Lee ${ }^{\star \star}$ \\ Departments of *Allergy \& Allied Respiratory Disorders and ${ }^{\ddagger}$ Thoracic Medicine, United Medical and Dental Schools, \\ Guy's Hospital, London SE1 9RT, United Kingdom
}

\begin{abstract}
Peripheral blood mononuclear cells (PBMC) were isolated from seven normal subjects, eight asthmatic subjects clinically sensitive to corticosteroids (CS), and eight asthmatic subjects clinically resistant to corticosteroids (CR). PBMC were cultured at $37^{\circ} \mathrm{C}$ for $24 \mathrm{~h}$ in the absence or presence of $10^{-16}$ to $10^{-4} \mathrm{M}$ hydrocortisone. Calcium ionophore (A23187)-activated neutrophils (PMN) primed by supernatants of PBMC from asthmatic subjects cultured in the absence of hydrocortisone generated approximately threefold more leukotriene $\mathbf{B}_{4}$ than PMN primed by supernatants of PBMC from normal subjects $(P<0.05)$. Incubation of PBMC derived from CS subjects with $10^{-8} \mathrm{M}$ hydrocortisone completely inhibited the production of the enhancing activity $(P<0.01)$, whereas in $C R$ subjects hydrocortisone at concentrations up to $10^{-4} \mathrm{M}$ did not suppress the release of enhancing activity. The enhancing activity was produced by monocytes. Enhancing activity eluted with an $M_{\mathrm{r}}$ of 3,000 D and a pI of 7.1. It eluted at $10 \%$ acetonitrile after reverse-phase HPLC. The activity was destroyed by heating to $60^{\circ} \mathrm{C}$ for $60 \mathrm{~min}$ and was sensitive to pronase treatment. The purified factor also enhanced superoxide generation by PMN which had been stimulated submaximally by phorbol myristate acetate.
\end{abstract}

\section{Introduction}

The airflow obstruction of the majority of patients with chronic and severe bronchial asthma will improve after treatment with corticosteroids. However, there are some patients in whom systemic or inhaled treatment with corticosteroids, even when given in very large doses, does not lead to any increases in forced expiratory volume in $1 \mathrm{~s}\left(\mathrm{FEV}_{1}\right) .{ }^{1}$ The asthma in such patients is usually severe, and they are seriously disabled for long periods of time. Carmichael et al. (1) defined corticoste-

Address reprint requests to Dr. Lee, Department of Allergy \& Allied Respiratory Disorders, United Medical and Dental Schools, Hunts House, 4th Floor, Guy's Hospital, London SE1 9RT, United Kingdom.

Received for publication 12 December 1988 and in revised form 17 July 1989.

1. Abbreviations used in this paper: BCA, bicinchonic acid; CR, corticosteroid-resistant (subject); CS, corticosteroid-sensitive (subject); $\mathrm{FEV}_{1}$, forced expiratory volume in $1 \mathrm{~s}$; RP-HPLC, reverse-phase HPLC; TFA, trifluoroacetic acid.

J. Clin. Invest.

(c) The American Society for Clinical Investigation, Inc.

$0021-9738 / 89 / 12 / 1930 / 12 \$ 2.00$

Volume 84, December 1989, 1930-1941 roid responsiveness in asthma as an increase in $\mathrm{FEV}_{1}$ of $>30 \%$ during a 7-d course of prednisolone treatment at $20 \mathrm{mg}$ daily. Corticosteroid resistance in asthmatic subjects was defined as an improvement in the $\mathrm{FEV}_{1}$ of $<15 \%$ after a similar course of prednisolone. Comparison of corticosteroid-resistant (CR) and -sensitive (CS) asthmatic subjects revealed that the CR asthmatic individuals tended to be older, with a longer history of asthma, and that their disease was frequently difficult to control. A family history of asthma was more frequent in CR asthmatic subjects, and their nonspecific bronchial responsiveness, as assessed by methacholine challenge, was increased relative to the $\mathrm{CS}$ asthmatic patients.

In CS asthmatic patients, complement receptor expression in monocytes was reduced after corticosteroid treatment as compared with cells from untreated patients (2). The reduction in complement receptor expression induced by corticosteroids was not observed in monocytes of $C R$ asthmatic subjects. These observations suggest that there may be a defect in glucocorticoid responsiveness in the monocytes of CR asthmatic individuals. These studies have been extended recently by the demonstration that $10^{-8}$ to $10^{-9} \mathrm{M}$ methylprednisolone, which substantially inhibited the growth of colonies from phytohemagglutinin-stimulated mononuclear cells of CS asthmatic subjects, had little effect on colony growth from the mixed mononuclear cells of CR asthmatic individuals (3).

Activated monocytes secrete cytokines which prime granulocytes for enhanced leukotriene generation after subsequent stimulation by calcium ionophore (4) or by IgG-coated Sepharose beads (5). Leukotrienes (LT) are derived from the metabolism of arachidonic acid by the 5-lipoxygenase pathway $(6,7)$ and are potent pro-inflammatory mediators. $\mathbf{L T B}_{4}$ is a chemotactic agent for granulocytes (8-10) and monocytes (11). $\mathrm{LTC}_{4}, \mathrm{LTD}_{4}$, and $\mathrm{LTE}_{4}$ increase vascular permeability $(12-15)$, contract nonvascular smooth muscle $(12,13)$, and augment nonspecific bronchial hyperresponsiveness in asthmatic subjects (16). Thus, a putative mechanism for corticosteroid action may be to inhibit the production of the mononuclear cell-derived cytokine(s) that prime granulocytes for enhanced leukotriene generation in CS but not in CR asthmatic patients. We have tested this hypothesis and have purified to homogeneity the major mononuclear cell-derived molecule in CR asthmatic patients, which enhances leukotriene generation in granulocytes.

\section{Methods}

Mononuclear cell donors. Peripheral blood mononuclear cells (PBMC) were obtained from three groups of subjects: normal healthy volunteers $(n=7), C S$ asthmatic subjects $(n=8)$, and CR asthmatic subjects $(n=8)$ (Table I). All asthmatic subjects were defined by a history of episodic wheezing and by a $>30 \%$ increase in $\mathrm{FEV}_{1}$ after inhalation of $400 \mu \mathrm{g}$ of albuterol. The clinical response to corticosteroid therapy was confirmed to be reproducible by testing the patients on at least three 
occasions. None of the subjects were studied within 1 mo of using corticosteroids.

Preparation of supernatants from cultured mononuclear cells. PBMC were isolated from heparinized blood by sedimentation on dextran 110 (Dextraven 110, CP Pharmaceuticals Limited, Wrexham, England) and centrifugation on Lymphoprep (Nycomed AS, Oslo, Norway) as previously described (17). The PBMC were washed three times in Hanks' balanced salt solution without calcium or magnesium (HBSS $^{--}$) (Flow Laboratories, Irvine, Scotland). The cells were then suspended at a concentration of $2 \times 10^{6}$ per $\mathrm{ml}$ in Eagle's minimal essential medium with Earle's salts and $2 \mathrm{mM}$ glutamine (Gibco Ltd., Paisley, Scotland) supplemented with $25 \mathrm{mM}$ Hepes and $0.1 \%$ bovine serum albumin (BSA) (supplemented MEM). $2 \mathrm{ml}$ of the cell suspension was added to $60-\mathrm{mm}$ plastic plates (Cell-Cult, Sterilin Ltd., Feltham, England), and the plates were then incubated in a humidified atmosphere of $5 \% \mathrm{CO}_{2}$ at $37^{\circ} \mathrm{C}$ for $60 \mathrm{~min}$. Nonadherent cells were then aspirated and the plates were washed twice with $2 \mathrm{ml}$ of supplemented MEM without BSA. A further $2 \mathrm{ml}$ of cell suspension was then added to the plates and incubated for $60 \mathrm{~min}$, and the nonadherent cells were removed as described above. $10^{-16}$ to $10^{-4} \mathrm{M}$ hydrocortisone sodium hemisuccinate (Upjohn Ltd., Crawley, England) in $2 \mathrm{ml}$ of supplemented MEM containing 10\% heat-inactivated fetal calf serum (FCS), or $2 \mathrm{ml}$ of culture medium without hydrocortisone was added to separate plates and the plates were cultured in a humidified atmosphere of $5 \% \mathrm{CO}_{2}$ at $37^{\circ} \mathrm{C}$ for $24 \mathrm{~h}$. At the end of the incubation period, cells were $>95 \%$ viable as assessed by trypan blue exclusion. The $24-\mathrm{h}$ culture supernatants were removed by aspiration. The supernatants were then centrifuged at $200 \mathrm{~g}$ for $10 \mathrm{~min}$ at $4^{\circ} \mathrm{C}$ to remove any cells. The supernatants were decanted and stored at $-20^{\circ} \mathrm{C}$. Control samples consisted of MEM containing 10\% FCS with or without hydrocortisone, in the absence of cells, which had been treated in an identical manner to the PBMC cultures.

Activation of neutrophils and assessment for mononuclear cell-derived enhancing activity for leukotriene generation. Neutrophils (PMN) were purified to $>90 \%$ from heparinized blood of healthy volunteers by dextran sedimentation, centrifugation through Lymphoprep, and lysis of erythrocytes with isotonic ammonium chloride as previously described $(17,18)$. PMN were washed three times in HBSS $^{--}$and resuspended in HBSS with calcium and magnesium $\left(\mathrm{HBSS}^{++}\right) / 20 \mathrm{mM}$ Hepes at $1 \times 10^{7} \mathrm{PMN} / \mathrm{ml}$. Separate portions of $5 \times 10^{5} \mathrm{PMN}$ in $50 \mu \mathrm{l}$ $\mathrm{HBSS}^{++} / 20 \mathrm{mM}$ Hepes were warmed to $37^{\circ} \mathrm{C}$ for $10 \mathrm{~min}$ and were then mixed with $25 \mu \mathrm{l}$ of control buffer or a specified dilution (up to 1:192) of the PBMC culture supernatants. PMN were then incubated

Table I. Clinical Characteristics of PBMC Donors

\begin{tabular}{lccc}
\hline & Normal & $\begin{array}{c}\text { Corticosteroid } \\
\text { sensitive }\end{array}$ & $\begin{array}{c}\text { Corticosteroid } \\
\text { resistant }\end{array}$ \\
\hline Number & 7 & 8 & 8 \\
Age $(\mathrm{yr})$ & $25.6 \pm 1.3$ & $58.0 \pm 5.8$ & $55.0 \pm 4.6$ \\
FEV $(\%$ predicted) & $98.6 \pm 2.7$ & $40.3 \pm 4.9$ & $47.2 \pm 4.7$ \\
Albuterol response & & & \\
$\quad(\%$ increase in & & & \\
FEV $)$ & - & $49.2 \pm 7.2$ & $40.9 \pm 4.0$ \\
Prednisolone & & & \\
response $(\%$ & & & \\
increase in & - & $62.6 \pm 8.1$ & $2.0 \pm 2.5$ \\
FEV $)$ & $0 / 7$ & $6 / 8$ & $4 / 8$ \\
Atopy & $0 / 7$ & $0 / 8$ & $1 / 8$ \\
Smokers & & & \\
& & &
\end{tabular}

Albuterol response is the percent increase in $\mathrm{FEV}_{\mathrm{I}}$ after administration of $400 \mu \mathrm{g}$ of albuterol via a metered dose inhaler. Prednisolone was taken for $2 \mathrm{wk}$ at a dose of $40 \mathrm{mg}$ a day. for 0-10 min before the addition of ionophore A23187 at final concentrations up to $10 \mu \mathrm{M}$ in $50 \mu \mathrm{l} \mathrm{HBSS}^{++} / 20 \mathrm{mM}$ Hepes, with dimethylsulfoxide at final concentrations of up to $0.1 \%$. After incubation with ionophore for periods of $0-10 \mathrm{~min}$ the reaction was quenched by rapid cooling to $4^{\circ} \mathrm{C}$ followed by centrifugation at $10,000 \mathrm{~g}$ for $30 \mathrm{~s}$. The supernatants were stored under argon at $-20^{\circ} \mathrm{C}$ until used for measurement of immunoreactive $\mathrm{LTB}_{4}$.

Preincubation of PMN with PBMC-derived supernatants did not affect viability of the cells as indicated by trypan blue exclusion.

Quantitation of $\mathrm{LTB}_{4}$. The concentrations of immunoreactive $\mathrm{LTB}_{4}$ in the PMN supernatants were assessed by separate specific radioimmunoassays (RIA) as previously described $(19,20)$.

Reverse-phase high-performance liquid chromatography (RPHPLC) analysis of the supernatants was performed on a C-18 ultrasilODS column $(4.6 \times 250 \mathrm{~mm})$ (Altex-Beckman, Berkeley, CA) at a flow rate of $1 \mathrm{ml} / \mathrm{min}$ in a mobile phase solvent of $65 \%$ methanol $/ 34.9 \%$ water $/ 0.1 \%$ acetic acid, $\mathrm{pH}$ 5.6. 1-ml fractions were collected and the absorbance of the eluates was continuously monitored with an on-line spectrophotometer (Waters model 990 Photodiode Array Detector, Millipore Corp., Bedford MA) at $269 \mathrm{~nm}$ for the predominant PMN product, $\mathrm{LTB}_{4}$. The column was calibrated for the retention times of synthetic leukotrienes, which were provided by Dr. B. Spur (Institut Henri Beaufour, Paris, France): $(5 S, 12 R)$-6-trans-LTB TB $_{4}(15.1 \pm 0.1$ min, $n=4),(5 S, 12 S)-6$-trans-LTB ${ }_{4}(16.2 \pm 0.1 \mathrm{~min}, n=4)$, and $\mathrm{LTB}_{4}$ $(20.3 \pm 0.4 \mathrm{~min}, n=4)$. To carry out RIA on eluate fractions from RP-HPLC, the fractions were dried under reduced pressure and were resuspended in $200 \mu \mathrm{l}$ Isogel-Tris buffer.

Cellular origin of enhancing activity. In three experiments, the monocytes or lymphocytes contaminating the adherent monocyte monolayers were lysed with specific antibodies and complement. After isolation and purification of mononuclear cells by adherence as already described, the culture medium was aspirated and replaced with 1 $\mathrm{ml}$ of supplemented MEM containing either a 1:10 final dilution of mouse anti-CD14 antibody directed against monocytes (Seralab Ltd., Crawley Down, UK), or a 1:20 final dilution of mouse anti-CD5 antibody (Seralab Ltd.) plus a 1:100 final dilution of goat polyvalent anti-human immunoglobulin antiserum (Seralab Ltd.), directed against $T$ and $B$ lymphocytes, respectively. The cells were incubated for $60 \mathrm{~min}$ at $37^{\circ} \mathrm{C}$ before the addition of rabbit complement (Seralab Ltd.) to a final dilution of $1: 10$. Cells were cultured for a further $60 \mathrm{~min}$ at $37^{\circ} \mathrm{C}$ after which the supernatant was aspirated. The remaining adherent cells were washed twice with $2 \mathrm{ml}$ of supplemented MEM and the supernatant was replaced with $2 \mathrm{ml}$ of supplemented MEM containing 10\% FCS. The remaining adherent mononuclear cells were cultured for $24 \mathrm{~h}$ at $37^{\circ} \mathrm{C}$ as described earlier. The mononuclear cells were stained with peroxidase stain (21) to quantitate monocytes. To identify lymphocytes, cells were reacted with fluorescein-conjugated anti-human Ig or fluorescein-conjugated anti-Leu-1 monoclonal antibody (Becton, Dickinson \& Co., Sunnyvale, CA) and were examined under a fluorescence microscope.

In three experiments, the nonadherent mononuclear cells removed during monocyte purification were suspended at the same concentration as the adherent cells in supplemented MEM containing 10\% FCS and cultured for $24 \mathrm{~h}$ at $37^{\circ} \mathrm{C}$ in an identical manner.

Supernatants from all experiments were tested in a 1:3 final dilution for $\mathrm{LTB}_{4}$ release-enhancing activity in PMN.

Purification and characterization of mononuclear cell-derived enhancing activity. 300- $\mu$ l samples of PBMC culture supernatant were applied to Sep Pak C-18 cartridges (Millipore Corp.) which had been prepared by priming with $2 \mathrm{ml}$ of methanol followed by $2 \mathrm{ml}$ of $\mathrm{H}_{2} \mathrm{O}$. The Sep Pak was then eluted with two sequential 2-ml volume sof $\mathrm{H}_{2} \mathrm{O}$, followed by elution with $4 \mathrm{ml}$ of methanol. Aqueous fractions were lyophilized and methanol extracts were dried under negative pressure. All samples were resuspended in $300 \mu \mathrm{l}$ of $\mathrm{HBSS}^{--}$and tested for their activity in enhancing $\mathrm{LTB}_{4}$ generation from $\mathrm{A} 23187$-activated PMN as described above. The percentage inhibition of activity by hydrocortisone was calculated using the following equation: [1 - $\left(\mathrm{LTB}_{4}\right.$ generation by PMN primed by PBMC supernatants cultured 
in the presence ot hydrocortisone $+\mathrm{LTB}_{4}$ generation by $\mathrm{PMN}$ primed by PBMC supernatants cultured in the absence of hydrocortisone)] $\times 100$. LTB $_{4}$ generation is the value (nanograms) obtained by substracting the amount of $\mathrm{LTB}_{4}$ generated by A23187-stimulated PMN which had been preincubated with the Sep Pak eluate derived from the culture medium, from the amount of $\mathrm{LTB}_{4}$ generated by A23187-stimulated PMN, which had been preincubated with the corresponding Sep Pak eluate derived from the PBMC supernatant.

The active fractions after Sep Pak fractionation were subjected to gel filtration chromatography on a TSK 3000 HPLC column (Anachem Ltd., Luton, England), which had been equilibrated with $0.25 \%$

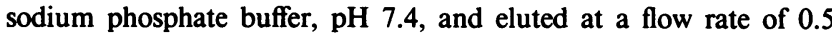
$\mathrm{ml} / \mathrm{min}$. 1-ml fractions were collected. The column was calibrated with thyroglobulin (mol wt 443,000), albumin (mol wt 66,000), carbonic anhydrase (mol wt 29,000), and vitamin $B_{12}(\mathrm{~mol} \mathrm{wt} 1,300)$. Eluate fractions were combined in groups of five consecutive fractions and were tested for enhancing activity.

Selected active fractions after TSK 3000 HPLC were combined, lyophilized, resuspended in $600 \mu \mathrm{l}$ of $\mathrm{H}_{2} \mathrm{O}$, and stored at $-20^{\circ} \mathrm{C}$ until used for desalting and further purification. 300- $\mu$ l samples of the pooled and concentrated gel filtration fractions were desalted by passage through a Sephadex $\mathrm{G} 10$ column $(0.9 \times 20 \mathrm{~cm})$ which was equilibrated with distilled $\mathrm{H}_{2} \mathrm{O}$. The desalted sample was then subjected to chromatofocusing (22-24) in a PBE 94 column $(0.9 \times 30 \mathrm{~cm}$, Pharmacia Fine Chemicals, Uppsala, Sweden) which had been equilibrated with $0.25 \%$ ethanolamine, $\mathrm{pH}$ 8.6. The sample was eluted with Polybuffer 96 (Pharmacia LKB Biotechnology, Uppsala, Sweden; 1:10 dilution) $\mathrm{pH} 4.7$ at $10 \mathrm{ml} / \mathrm{h}$. 2-ml fractions were collected. The $\mathrm{pH}$ of eluent fractions was adjusted with $0.1 \mathrm{M} \mathrm{HCl}$ or $0.1 \mathrm{M} \mathrm{NaOH}$ as appropriate to $\mathrm{pH}$ 7.4. Each eluate fraction was tested for enhancing activity on PMN.

The active eluate fractions after chromatofocusing were combined

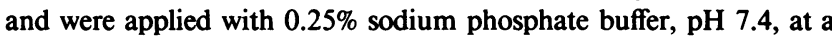
flow rate of $0.5 \mathrm{ml} / \mathrm{min}$. $1-\mathrm{ml}$ fractions were collected. The column was calibrated with ovalbumin (mol wt 40,000), chymotrypsinogen (mol

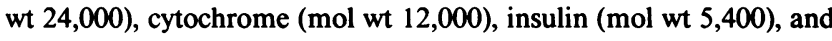
vitamin $B_{12}$ (mol wt 1,300). Each eluate fraction was tested for enhancing activity as already described.

Protein estimation was performed on eluant fractions following size exclusion chromatography using a bicinchonic acid (BCA) assay kit (Sigma Chemical Co., St. Louis, MO). Calibration was carried out using serial dilutions of BSA (Sigma Chemical Co.).

RP-HPLC analysis of enhancing activity. RP-HPLC analysis of biologic active peptides was performed on a $\mathrm{C}_{18}$ spherisorb-ODS column $(4.6 \times 250 \mathrm{~mm})$ (Anachem, London, UK) at a flow rate of 1 $\mathrm{ml} /$ minute. Mobile phase: solvent A was $0.1 \%$ trifluoroacetic acid (TFA) in water and solvent $B$ was $0.1 \%$ TFA in acetonitrile. The column was equilibrated with $10 \%$ solvent B in solvent A. After application of $100 \mu$ l of the sample, the column was washed with the equilibrating buffer for $10 \mathrm{~min}$. Then a slope gradient was established from $10-40 \%$ solvent B over $30 \mathrm{~min}$. 1- $\mathrm{ml}$ fractions were collected and the absorbance of the eluates at 215,242 , and $254 \mathrm{~nm}$ was continuously monitored with an on-line spectrophotometer (Waters 990 Photodiode Assay Detector). Each eluate function was lyophilized, resuspended in $\mathrm{HBSS}^{++}$, and tested for enhancing activity as already described.

${ }^{125}$ I-Iodination and SDS-PAGE of 3,000-D peptide. ${ }^{125}$ I-Iodination was carried out following the method of Bolton and Hunter (25). 100 $\mu \mathrm{l}$ of purified cytokine was lyophilized and resuspended in $20 \mu \mathrm{l}$ of 0.1 $\mathrm{M}$ borate buffer, $\mathrm{pH} 8.5$, containing $0.005 \mu \mathrm{Ci}$ of $N$-succinimidyl-3(4-hydroxy,5-[125I]iodophenyl) propionate. The resulting solution was incubated on ice for $15 \mathrm{~min}$, after which the remaining unchanged ester was reacted with glycine by the addition of $10 \mu \mathrm{l}$ of $0.1 \mathrm{M}$ borate buffer containing $0.2 \mathrm{M}$ glycine for a further $5 \mathrm{~min}$ at $0^{\circ} \mathrm{C}$.

The ${ }^{125}$ I-labeled peptide solution was lyophilized and resuspended in $30 \mu \mathrm{l}$ of sample buffer solution containing $10 \mathrm{mM}$ Tris, $1 \mathrm{mM}$ EDTA, 2.5\% SDS, 5\% 2-mercaptoethanol, and $0.01 \%$ bromphenyl blue, $\mathrm{pH} 8.0$, and then heated to $100^{\circ} \mathrm{C}$ for $1 \mathrm{~min}$. 3- $\mu$ l samples were subjected to gel electrophoresis on a Phast System flat bed gel electro- phoresis system (Pharmacia LKB Biotechnology, Uppsala, Sweden), using a $20 \%$ acrylamide gel in combination with a $7.5 \%$ acrylamide stacking gel.

Gels were fixed in an aqueous solution of $3 \%$ sulfosalicylic acid and $10 \% \mathrm{TFA}$, then dried and autoradiographed for $72 \mathrm{~h}$ at $-70^{\circ} \mathrm{C}$. After exposure the gels were stained with Coomassie Blue. After destaining, gels were stored in 5\% glycerol and $10 \%$ acetic acid in $\mathrm{H}_{2} \mathrm{O}$ until photographed. Gels were calibrated with unlabeled low molecular mass standards of $16,950,14,400,8,160,6,210$, and 2,510 D (Sigma Chemical Co.)

Enzyme digestion and heat denaturation. Enzyme digestion and heat denaturation were performed on the mononuclear cell-derived enhancing activity that had been partially purified by gel filtration. 10 $\mu l$ of the pooled and concentrated samples containing enhancing activity that were derived from two CS asthmatic and three CR asthmatic subjects after TSK 3,000 HPLC, was mixed with either $10 \mu \mathrm{l}$ pronase (Sigma Chemical Co.) in a final concentration of $1 \mu \mathrm{g} / \mathrm{ml}$, or neuraminidase (Sigma Chemical Co.) in a final concentration of $0.5 \mathrm{U} / \mathrm{ml}$. Samples containing pronase were incubated for $15 \mathrm{~min}$ at $37^{\circ} \mathrm{C}$ and then diluted with water to a final volume of $150 \mu$ l. Samples containing neuraminidase were incubated for $45 \mathrm{~min}$ at $37^{\circ} \mathrm{C}$ and then similarly diluted. The effect of heat on the enhancing activity was studied by diluting a $10-\mu \mathrm{l}$ sample to $150 \mu \mathrm{l}$ with water and then heating to $60^{\circ} \mathrm{C}$ for $1 \mathrm{~h}$. Controls consisted of identically treated cytokine-free control medium. $5 \times 10^{5} \mathrm{PMN}$ in $50 \mu \mathrm{l}$ of $\mathrm{HBSS}^{++} / 20 \mathrm{mM}$ Hepes were preincubated with $25 \mu \mathrm{l}$ of enzyme- or heat-treated cytokine, or control medium, for $2.5 \mathrm{~min}$. The mixture was then stimulated with $2.5 \mu \mathrm{M}$ A23187 under optimal conditions as previously described and the quantities of immunoreactive $\mathrm{LTB}_{4}$ released into the supernatants were measured by RIA.

Preparation and activation of $\left[{ }^{3} \mathrm{H}\right]$ arachidonic acid-labled PMN. In three experiments purified PMN were suspended at a concentration of $1 \times 10^{7} / \mathrm{ml}$ in $\mathrm{HBSS}^{++} / 20 \mathrm{mM}$ Hepes containing $0.1 \%$ BSA. $1 \mathrm{ml}$ of PMN suspension was incubated with $5.0 \mu \mathrm{Ci}\left[{ }^{3} \mathrm{H}\right]$ arachidonic acid (Amersham International P.L.C., Amersham, UK) for $60 \mathrm{~min}$ at $37^{\circ} \mathrm{C}$. PMN were then washed twice in $\mathrm{HBSS}^{++} / \mathrm{Hepes} / \mathrm{BSA}$ and once in HBSS $^{++} /$Hepes and resuspended at a concentration of $2 \times 10^{7} / \mathrm{ml}$ in

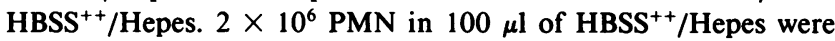
warmed to $37^{\circ} \mathrm{C}$ for $10 \mathrm{~min}$ and were then mixed with $50 \mu \mathrm{l}$ of control buffer or purified cytokine for $2.5 \mathrm{~min} .100 \mu \mathrm{l}$ of A23187 solution was then added to achieve a final concentration of $2.5 \mu \mathrm{M}$ and the mixture was incubated for a further $5 \mathrm{~min}$. The reaction was stopped by rapid cooling to $4^{\circ} \mathrm{C}$ and centrifugation at $10,000 \mathrm{~g}$ for $30 \mathrm{~s} .200 \mu \mathrm{l}$ of PMN supernatant was removed and analyzed for lipoxygenase products by RP-HPLC as described earlier. 2-ml fractions were collected and added to $15 \mathrm{ml}$ of liquid scintillant (Supersolv X, Koch-Light Ltd., Haverhill, UK) and the radioactivity in each was measured.

Superoxide anion $\left(0_{2}^{-}\right)$assay. In six experiment with PMN from different donors the production of $\mathrm{O}_{2}^{-}$by $\mathrm{PMN}$ preincubated with purified cytokine was measured by the capacity of $\mathrm{O}_{2}^{-}$to reduce ferricytochrome $c$ to ferrocytochrome $c$ (26). Control PMN preparations were preincubated with buffer only. Purified PMN were suspended at 4 $\times 10^{7} / \mathrm{ml}$ in $\mathrm{HBSS}^{++} / 20 \mathrm{mM}$ Hepes. $50 \mu \mathrm{l}$ of PMN suspension was warmed to $37^{\circ} \mathrm{C}$ for $10 \mathrm{~min}$ and then preincubated with either control buffer or a 1:3 dilution of cytokine for $2.5 \mathrm{~min} .25 \mu \mathrm{l}$ of $\mathrm{HBSS}^{++} / \mathrm{Hepes}$ with ferricytochrome $c$, type VI $(6.25 \mathrm{mg} / \mathrm{ml}$, Sigma Chemical Co.) either with or without superoxide dismutase (SOD, $500 \mu \mathrm{g} / \mathrm{ml}$, Sigma Chemical Co.) and $25 \mu \mathrm{l}$ of $\mathrm{HBSS}^{++} /$Hepes containing phorbol myristate acetate (PMA, 0.25-2500 $\mu \mathrm{g} / \mathrm{ml}$, Sigma Chemical Co.) were then added to stimulate the respiratory burst. PMN reaction mixtures were then incubated at $37^{\circ} \mathrm{C}$ for $45 \mathrm{~min}$, after which cells were sedimented at $10,000 \mathrm{~g}$ for $30 \mathrm{~s}$ and the supernatants were removed.

Supernatants were diluted 1:4 in $\mathrm{HBSS}^{--}$and assayed for reduction of ferricytochrome $c$ by spectroscopic analysis. Nanomoles of cytochrome $c$ reduced were calculated from the increase in absorbance measured using an absorption coefficient of $29.5 \mathrm{mM}^{-1} \mathrm{~cm}^{-1}$ at 550 $\mathrm{nm}$. Superoxide-dependent cytochrome $c$ reduced was calculated by subtraction of the value for cytochrome $c$ reduced measured in the 
reaction mixtures containing SOD from the value measured in the reaction mixtures without SOD. Results were expressed as nanomoles of cytochrome $c$ reduced per $5 \times 10^{6}$ neutrophils.

Statistics. Statistics were performed by analysis of variance. A $P$ value of $<0.05$ was considered significant for each. Correlations were analysed by linear regression test.

\section{Results}

Enhanced generation of $\mathrm{LTB}_{4}$ by ionophore-stimulated PMN after preincubation in PBMC supernatants derived from asthmatic subjects. The effect of preincubating PMN for 1-10 min in a 1:3 dilution of PBMC culture supernatants on their subsequent maximal abilities to generate $\mathrm{LTB}_{4}$ when stimulated by $2.5 \mu \mathrm{M} \mathrm{A} 23187$ is shown in Fig. 1. $\mathrm{LTB}_{4}$ generation from A23187-activated PMN increased in a time-dependent manner to reach a maximum at $2.5 \mathrm{~min}$ of preincubation time and decreased rapidly thereafter. PMN preincubated with PBMC culture supernatants from each of six CS asthmatic, six CR asthmatic, and six normal subjects generated $405 \pm 45 \%(P$ $<0.05), 352 \pm 83 \%(P<0.05)$, and $105 \pm 25 \%(P<0.05)$ more $\mathrm{LTB}_{4}$, respectively (mean \pm SEM), than PMN preincubated in control culture medium. PMN preincubated with control culture medium generated $10.0 \pm 3.5 \mathrm{ng}$ of $\mathrm{LTB}_{4}$ (mean $\pm \mathrm{SEM}, n$ $=6)$.

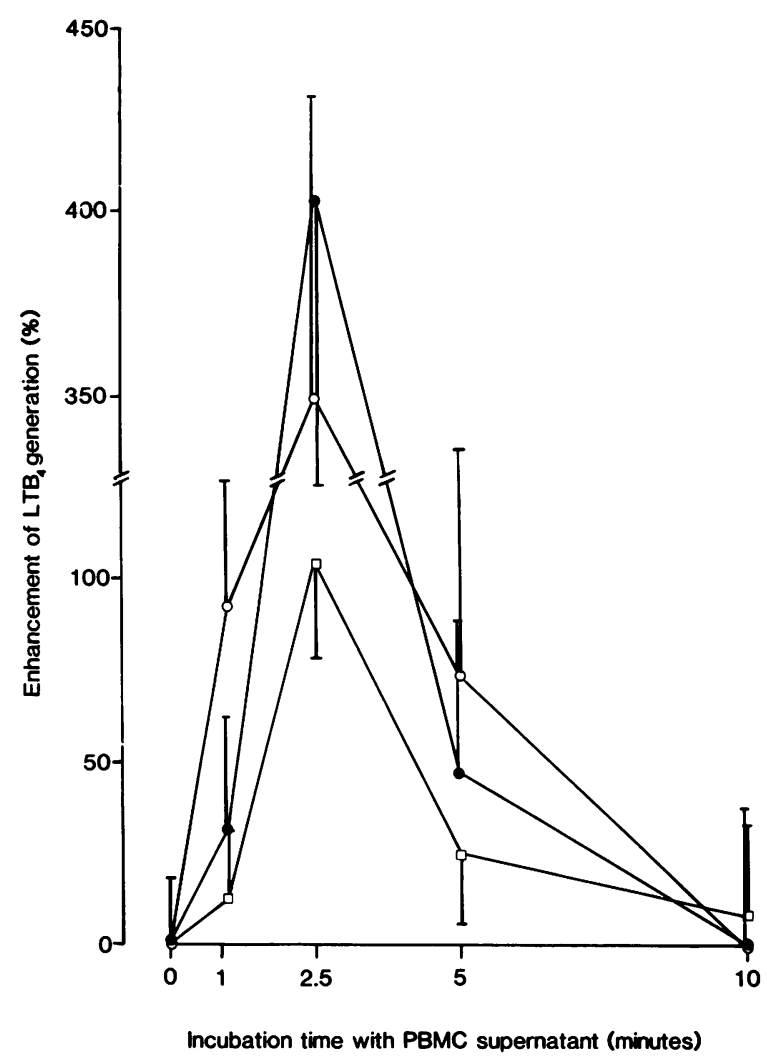

Figure 1. Time-dependent enhancing effects of PBMC culture supernatants on the subsequent generation of $\mathrm{LTB}_{4}$ by ionophore-activated neutrophils (PMN). PMN were pretreated with a 1:3 dilution of PBMC culture supernatants from six CS asthmatic subjects (๑), six CR asthmatic subjects (O), and six normal donors ( $\square$ ), and then stimulated with $2.5 \mu \mathrm{M}$ ionophore for 2.5 and $5 \mathrm{~min}$ in PMN preincubated with normal PBMC supernatants and asthmatic supernatants, respectively. Values are mean \pm SEM. Six normal subjects served as donors for PMN.
The dose-dependent enhancing effect of supernatants derived from cultures of PBMC isolated from two different $\mathrm{CR}$ asthmatic subjects on the subsequent $\mathrm{LTB}_{4}$ generation by PMN stimulated by $2.5 \mu \mathrm{M} \mathrm{A} 23187$ for $5 \mathrm{~min}$ at $37^{\circ} \mathrm{C}$ was assessed in separate experiments (Fig. 2). Maximum enhancement of $\mathrm{LTB}_{4}$ generation by A23187-activated PMN occurred at 1:3 dilution, with progressively less enhancement of $\mathrm{LTB}_{4}$ biosynthesis with increasing dilutions of the PBMC culture supernatants. The enhancement was lost at dilutions $>1: 24$.

Time course and dose dependency of ionophore stimulation after incubation of PMN with PBMC supernatants. The dose and time dependence of $A 23187$ stimulation was evaluated for PMN from normal donors preincubated for $2.5 \mathrm{~min}$ in a $1: 3$ dilution of PBMC culture supernatants derived from eight CS asthmatic subjects, eight $\mathrm{CR}$ asthmatic subjects, and seven normal volunteers. In seven experiments, $\mathrm{LTB}_{4}$ generation in PMN which had been preincubated with PBMC culture supernatants from normal donors peaked at $2.5 \mathrm{~min}$ (Fig. 3). In 16 further experiments on PMN preincubated with PBMC culture supernatants from eight $\mathrm{CS}$ and eight $\mathrm{CR}$ asthmatic subjects, maximum quantities of $\mathrm{LTB}_{4}$ were detected at $5 \mathrm{~min}$ and these were on average 2.5-fold greater than those generated under optimal conditions by PMN preincubated with PBMC culture supernatants from normal subjects $(P<0.05)$.

In three experiments, PMN were stimulated with increasing concentrations of $\mathrm{A} 23187$ for 2.5 and $5 \mathrm{~min}$ in normal and asthmatic subjects, respectively, after $2.5 \mathrm{~min}$ of preincubation with PBMC culture supernatants derived from each of three $\mathrm{CS}$ asthmatic, three CR asthmatic, and three normal subjects or culture medium alone (Fig. 4). $\mathrm{LTB}_{4}$ generation increased

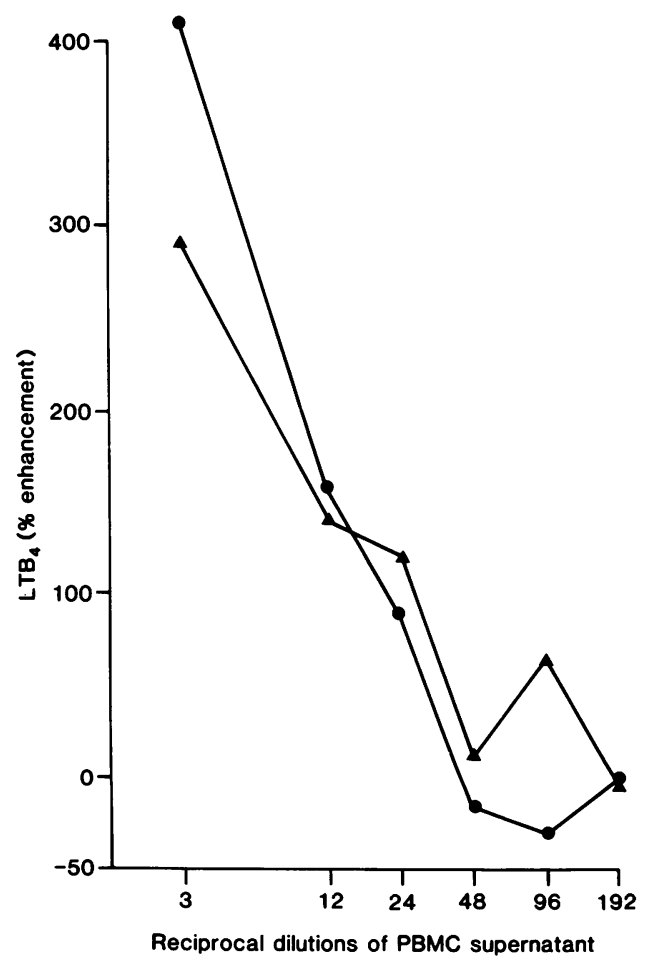

Figure 2. Concentration-dependent enhancing effects of PBMC culture supernatants on the subsequent generation of $\mathrm{LTB}_{4}$ by ionophore-activated neutrophils (PMN). PMN were incubated with culture supernatant for $2.5 \mathrm{~min}$ and then stimulated with $2.5 \mu \mathrm{M}$ ionophore. Symbols represent different PBMC donors. 


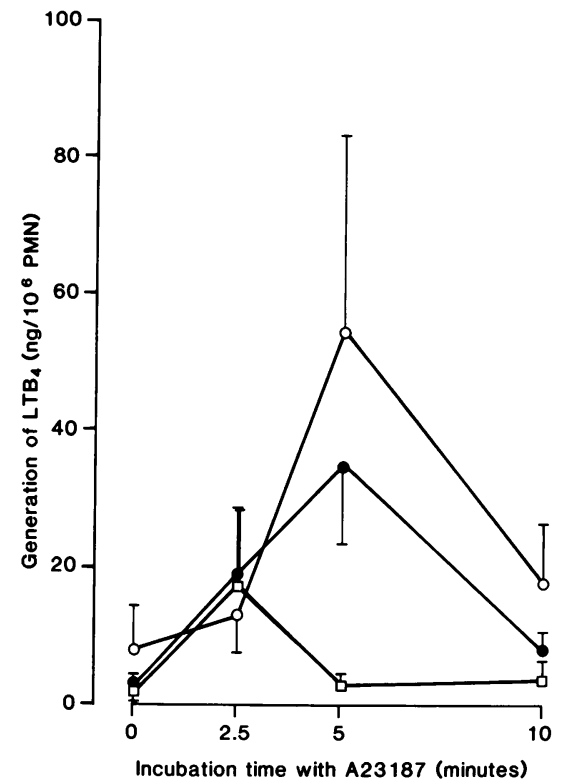

Figure 3. Effect of pretreatment of neutrophils (PMN) for $2.5 \mathrm{~min}$ with a 1:3 dilution of PBMC culture supernatants from eight CS (•) asthmatic subjects, eight $C R(O)$ asthmatic subjects, and seven normal ( $\square$ ) subjects on the time course of subsequent $\mathrm{LTB}_{4}$ generation after the addition of $2.5 \mu \mathrm{M} \mathrm{A23187}$. Values are mean \pm SEM. Eight normal subjects served as donors for PMN.

in a dose-dependent manner, with maximal generation occurring at $2.5 \mu \mathrm{M} \mathrm{A} 23187$ in all experiments. At all concentrations of ionophore studied, PMN preincubated with PBMC culture supernatants from CS and CR asthmatic subjects generated more $\mathrm{LTB}_{4}$ than those preincubated with PBMC supernatants from normal subjects $(P<0.05,<0.05$, respectively). In the absence of A23187 stimulation, there was no enhancement of $\mathrm{LTB}_{4}$ generation by culture supernatants derived from either asthmatic or normal subjects.

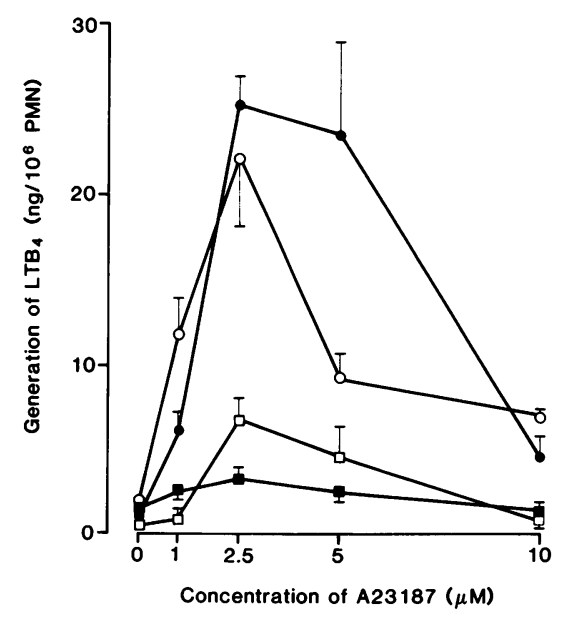

Figure 4. Effect of pretreatment of neutrophils (PMN) for $2.5 \mathrm{~min}$ with a 1:3 dilution of PBMC culture supernatants from three CS (•) asthmatic subjects, three CR (O) asthmatic subjects, three normal ( $\square$ ) subjects, or control medium ( $\square$ ) on the ionophore dose-dependent generation of $\mathrm{LTB}_{4}$. PMN were incubated with A23187 for $2.5 \mathrm{~min}$ in normal culture supernatant and control medium-treated groups and $5 \mathrm{~min}$ in CS and CR culture medium-treated groups. Values are mean \pm SEM. Three normal subjects served as donors for PMN.
Analysis by RP-HPLC of immunoreactive $\mathrm{LTB}_{4}$. To establish that the immunoreactive $\mathrm{LTB}_{4}$ represented a single product, the supernatants from $10^{6} \mathrm{PMN}$ activated by $2.5 \mu \mathrm{M}$ ionophore for $5 \mathrm{~min}$ at $37^{\circ} \mathrm{C}$ after pretreatment with $1: 3$ dilution of PBMC culture supernatants derived from each of three CS asthmatic, three CR asthmatic, and three normal donors, or control medium for $2.5 \mathrm{~min}$ were resolved by RP-HPLC, and the fractional eluates were assessed by RIA for immunoreactive $\mathrm{LTB}_{4}$. In all experiments, there was only one peak of immunoreactivity which eluted at the same retention time as that of a synthetic $\mathrm{LTB}_{4}$ reference standard. The supernatants derived from PMN activated in the presence of PBMC culture supernatants derived from the three CS asthmatic subjects contained 75, 52, and $46 \mathrm{ng}$ of $\mathrm{LTB}_{4}$ after RP-HPLC, whereas the supernatants from PMN activated after pretreatment with control medium contained 21,17 , and $9 \mathrm{ng}$ of $\mathrm{LTB}_{4}$, respectively, after RP-HPLC.

The supernatants derived from PMN pretreated with PMBC culture supernatants from the three CR asthmatic subjects contained 64,39 , and $37 \mathrm{ng}$ of $\mathrm{LTB}_{4}$ after RP-HPLC, whereas the supernatants from PMN activated after pretreatment with control medium contained 22,15 , and $12 \mathrm{ng}$ of $\mathrm{LTB}_{4}$, respectively, after RP-HPLC.

The supernatants derived from PMN activated after pretreatment with PBMC culture supernatants derived from the three normal subjects contained 27, 25, and $22 \mathrm{ng}$ of $\mathrm{LTB}_{4}$ after RP-HPLC, whereas those from PMN activated after pretreatment with control medium contained 18,13 , and $9 \mathrm{ng}$, respectively, after RP-HPLC. In all experiments, there was $>84 \%$ recovery of immunoreactive $\mathrm{LTB}_{4}$ applied for resolution by RP-HPLC. The quantities of $\mathrm{LTB}_{4}$ as assessed by integrated UV absorbance at $269 \mathrm{~nm}$ were virtually identical to those measured by RIA in all experiments (data not shown).

Generation of lipoxygenase products by $\left[{ }^{3} \mathrm{H}\right]$ arachidonic acid-labeled PMN activated with A23187. The enhancement in the quantities of $\mathrm{LTB}_{4}$ detected in supernatants from PMN preincubated with cytokine derived from CR subjects could have been due to increased biosynthesis, decreased omega oxidation, or both. Therefore, the radioactive counts originating from membrane-derived $\left[{ }^{3} \mathrm{H}\right]$ arachidonic acid and eluting with the $\omega$-oxidation products of $\mathrm{LTB}_{4}$ during HPLC were compared with those eluting with $\mathrm{LTB}_{4}$ (Table II). In PMN preincubated with cytokine, there was enhancement of the total quantities of $\mathrm{LTB}_{4}$, as indicated by the sum of $\mathrm{LTB}_{4}$ and $\omega$-oxidation products of $\mathrm{LTB}_{4}$, as compared with $\mathrm{PMN}$ preincubated with control buffer $(P<0.05)$. There was no significant difference in the percentage of total $\mathrm{LTB}_{4}$ measured as $\omega$-oxidation products between PMN preincubated with cytokine and those preincubated with control buffer. Thus, the increased appearance of $\mathrm{LTB}_{4}$ was attributed to increased biosynthesis.

Cellular origin of enhancing activity. To determine the cell of origin of the enhancing activity, mononuclear cells were fractionated into adherent and nonadherent cells and these were cultured separately for $24 \mathrm{~h}$ (Table III). In three experiments with mononuclear cells isolated from three different $C R$ subjects, the enhancing activity was found in culture supernatants from adherent mononuclear cells but not in supernatants from nonadherent cells. When $90 \%$ of the lymphocytes that contaminated the adherent monocytes were lysed with antiCD5 and anti-human Ig antibodies plus complement, the enhancing activity of supernatants for ionophore-stimulated 
Table II. Analysis of $\mathrm{LTB}_{4}$ and $\omega$-Oxidation Metabolites of $L T B_{4}$ Produced by $\left[{ }^{3} \mathrm{H}\right]$ Arachidonic Acid-labeled PMN Stimulated with $2.5 \mu M$ A23187

\begin{tabular}{lcc}
\hline \multicolumn{1}{c}{ Preincubation } & "Total $\mathrm{LTB}_{4}$ "* & $\omega$-Metabolites \\
\hline & $c p m$ & $\%$ \\
Control buffer & $252 \pm 26$ & $58 \pm 4$ \\
Cytokine & $602 \pm 90$ & $52 \pm 4$ \\
& $(P<0.05)$ & $(\mathrm{NS})$
\end{tabular}

In three experiments with PMN from different donors, $2 \times 10^{6} \mathrm{PMN}$ labeled with $\left[{ }^{3} \mathrm{H}\right]$ arachidonic acid, were incubated with either control buffer or a 1:3 dilution of cytokine (sequentially purified by TSK 3000 HPLC, chromatofocusing, Sephadex G50, and RP-HPLC) for $2.5 \mathrm{~min}$, then stimulated with $2.5 \mu \mathrm{M}$ A23187 for $5 \mathrm{~min}$. Supernatants were resolved by RP-HPLC and quantitated as counts per minute $(\mathrm{cpm}) / 10^{6} \mathrm{PMN}$. Values are mean $\pm \mathrm{SEM}$.

* Total $\mathrm{LTB}_{4}$ represents the sum of the values for $\mathrm{LTB}_{4}$ and $\omega$ metabolites of $\mathrm{LTB}_{4}$ in each experiment. NS, not significant.

$\mathrm{LTB}_{4}$ generation was not diminished (Table III). When $>85 \%$ of the adherent monocytes were lysed with anti-CD 14 antibody plus complement, the enhancing activity was abolished.

Suppression of enhancing activity from cultured PBMC by hydrocortisone. The effects of incubating PBMC from eight $\mathrm{CR}$ and eight $\mathrm{CS}$ asthmatic subjects for $24 \mathrm{~h}$ in the absence or presence of $10^{-16}$ to $10^{-4} \mathrm{M}$ hydrocortisone on the production of the enhancing activity are shown in Fig. 5. In the absence of hydrocortisone, PMN preincubated with 1:3 dilution of PBMC culture supernatants derived from eight CR asthmatic, eight CS asthmatic, or seven normal subjects or control culture medium alone, produced $61.9 \pm 26.1,49.2 \pm 11.2,21.6 \pm 8.6$, and $10.8 \pm 3.5 \mathrm{ng} \mathrm{LTB}_{4} / 10^{6} \mathrm{PMN}$ (mean \pm SEM), respectively, after stimulation with A23187. PMN which had been preincubated with PBMC culture supernatants from CS and CR asthmatic subjects generated significantly more $\mathrm{LTB}_{4}$ than

Table III. Identification of the Cell Source of $L_{T} B_{4}$ Generation-enhancing Activity in Cultures of PBMC

\begin{tabular}{|c|c|c|c|c|c|}
\hline \multirow[b]{3}{*}{ Cell source } & \multicolumn{2}{|c|}{ Treatment } & \multirow{2}{*}{\multicolumn{3}{|c|}{ Generation of $\mathrm{LTB}_{4}$}} \\
\hline & \multirow{2}{*}{$\begin{array}{l}\text { Anti-CD5 } \\
+ \text { anti-lg }\end{array}$} & \multirow[b]{2}{*}{ Anti-CD14 } & & & \\
\hline & & & Expt. 1 & Expt. 2 & Expt. 3 \\
\hline & & & & $g / 10^{6} P M$ & \\
\hline \multirow[t]{3}{*}{ Adherent PBMC } & - & - & 10.4 & 10.8 & 17.1 \\
\hline & + & - & 8.4 & 12.5 & 15.6 \\
\hline & - & + & 1.8 & 5.5 & 8.1 \\
\hline Nonadherent PBMC & - & - & 2.4 & 3.9 & 9.1 \\
\hline Control medium & - & - & 0.9 & 5.2 & 7.6 \\
\hline
\end{tabular}

Adherent PBMC were treated with either anti-CD5 plus anti-Ig for $1 \mathrm{~h}$, or anti-CD14 for $1 \mathrm{~h}$, at $37^{\circ} \mathrm{C}$ followed by incubation with complement for $1 \mathrm{~h}$. Remaining cells were washed twice and then cultured for $24 \mathrm{~h}$. Nonadherent PBMC were suspended at the same concentration as adherent cells and cultured for $24 \mathrm{~h}$. Supernatants were tested by preincubation with PMN for 2.5 min at a 1:3 dilution for enhancement of $\mathrm{LTB}_{4}$ generation. PMN were obtained from three separate, normal donors and stimulated with $2.5 \mu \mathrm{M}$ ionophore at $37^{\circ} \mathrm{C}$ for $5 \mathrm{~min}$. Each value is the mean of duplicate determinations by radioimmunoassay of duplicate experiments.

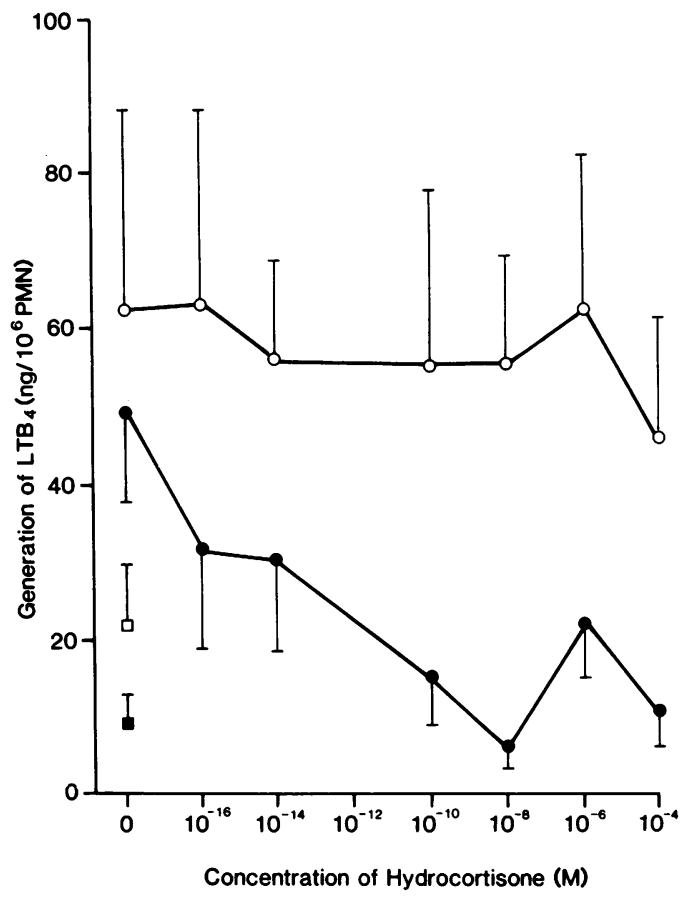

Figure 5. Effect of incubation of PBMC cultures with control medium or medium containing $10^{-16}$ to $10^{-4} \mathrm{M}$ hydrocortisone on the production of enhancing activity. Neutrophils (PMN) were pretreated for $2.5 \mathrm{~min}$ with a 1:3 dilution of PBMC culture supernatant

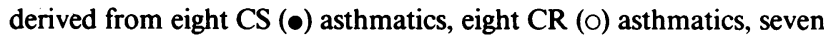
normal subjects $(\square)$, or control medium $(\square)$ and then stimulated with $2.5 \mu \mathrm{M}$ ionophore for 2.5 and $5 \mathrm{~min}$ for normal and asthmatic subjects, respectively. Values are mean \pm SEM. Eight normal subjects served as donors for PMN.

those preincubated with PBMC culture supernatants from normal subjects $(P<0.05)$. PMN pretreated with PBMC supernatants from normal subjects produced more $\mathrm{LTB}_{4}$ than PMN pretreated with culture medium $(P<0.05)$. There was no significant difference between the CS and CR asthmatic individuals. In CS asthmatic subjects, hydrocortisone suppressed the production of the enhancing activity in a dose-dependent manner. There was significant inhibition at $10^{-8}$, $10^{-6}$, and $10^{-4} \mathrm{M}$ hydrocortisone $(P<0.01,<0.05,<0.01$, respectively) and complete inhibition of enhancing activity occurred at $10^{-8} \mathrm{M}$ hydrocortisone. In CR asthmatic subjects there was no inhibition of PBMC-derived enhancing activity with increasing concentrations of hydrocortisone up to $10^{-4} \mathrm{M}$.

Increasing concentrations of hydrocortisone up to $10^{-4} \mathrm{M}$ did not alter significantly the quantities of $\mathrm{LTB}_{4}$ generated by ionophore-activated PMN preincubated with control culture medium (data not shown).

Correlation between suppression of PBMC-derived enhancing activity by hydrocortisone and improvement in FEV after treatment with prednisolone. There was a correlation between the percent suppression of PBMC-derived enhancing activity by $10^{-8} \mathrm{M}$ hydrocortisone and the percentage increase in $\mathrm{FEV}_{1}$ in asthmatic subjects after a 2-wk course of prednisolone at a dose of $40 \mathrm{mg}$ per day. $(r=0.68, P=0.005)$. There was a similar correlation between suppression of activity at $10^{-4} \mathrm{M}$ hydrocortisone and the increase in $\operatorname{FEV}_{1}(r=0.67$, $P=0.006)$. 
Fractionation of PBMC-derived culture supernatants by Sep Pak C-18 cartridges. As maximal suppression of the PBMC-derived enhancing activity in CS asthmatic subjects occurred at $10^{-8} \mathrm{M}$ hydrocortisone, initial fractionation of the supernatants on Sep Pak C-18 cartridges was performed on each of the supernatants of PBMC isolated from three CS and three CR asthmatic subjects which had been cultured in the presence or absence of $10^{-8} \mathrm{M}$ hydrocortisone. All eluant fractions after Sep Pak fractionation contained enhancing activity (Table IV). The activities in the aqueous fractions 2 and 3 were suppressed by an average of $91 \%$ and $95 \%$, respectively, by $10^{-8} \mathrm{M}$ hydrocortisone in CS but not in CR asthmatic subjects. The activities of fraction 1 derived from both CS and CR patients were sensitive to corticosteroid preincubation whereas the activities of fraction 4 were not attenuated by hydrocortisone.

Size and pI of PBMC-derived enhancing activity. The size of the molecule(s) carrying enhancing activity in PBMC culture supernatants, and the effects of hydrocortisone on the production of this activity by PBMC, were assessed by chromatography of the combined Sep Pak eluant fractions 2 and 3 derived from each of three CS and three CR asthmatic subjects on a TSK 3,000 HPLC column. Representative experiments from one subject in each group are shown in Fig. 6. In all CS asthmatic subjects there was one major peak of enhancing

Table IV. Activity of Eluant Fractions after Sep Pak C-18 Filtration

\begin{tabular}{lccc}
\hline & & \multicolumn{2}{c}{ Generation of $\mathrm{LTB}_{4}$} \\
\cline { 3 - 4 } Subject group & $\begin{array}{c}\text { Fraction } \\
\text { number }\end{array}$ & \multicolumn{2}{c}{$n g / 10^{6} P M N$} \\
\cline { 3 - 4 } Co hydrocortisone & Hydrocortisone $10^{-8} \mathrm{M}$ \\
sensitive & \multicolumn{3}{c}{$32.6 \pm 7.0$} \\
& 3 & $79.6 \pm 17.2$ & $15.4 \pm 2.8$ \\
& 4 & $150.0 \pm 40.8$ & $16.0 \pm 9.2$ \\
Corticosteroid & 1 & $40.2 \pm 21.6$ & $65.6 \pm 22.4$ \\
resistant & 2 & $89.6 \pm 32.8$ & $27.6 \pm 5.6$ \\
& 3 & $(5.2 \pm 0.2)$ & $(8.0 \pm 1.2)$ \\
& 4 & $70.4 \pm 21.6$ & $24.8 \pm 8.2$ \\
& & $76.6 \pm 9.8$ & $87.4 \pm 5.6$ \\
& Original & $60.0 \pm 41.0$ & $84.2 \pm 27.8$ \\
& & $70.4 \pm 11.2$ & $105.2 \pm 20.6$ \\
& & $(11.4 \pm 0.8)$ & $(14.4 \pm 6.4)$ \\
\hline
\end{tabular}

Culture supernatants derived from PBMC cultured in the absence or presence of $10^{-8} \mathrm{M}$ hydrocortisone were filtered on $\mathrm{C}-18$ cartridges which had been equilibrated with $\mathrm{H}_{2} \mathrm{O}$ and methanol and eluted with $2 \times 2 \mathrm{ml}$ of $\mathrm{H}_{2} \mathrm{O}$ followed by $4 \mathrm{ml}$ methanol. Aqueous eluant fractions were dried under negative pressure and similarly resuspended. Fractions were tested in a 1:3 dilution for $\mathrm{LTB}_{4}$ generationenhancing activity in PMN obtained from four different, normal donors. PMN were preincubated for $2.5 \mathrm{~min}$ with the fractions and then stimulated with $2.5 \mu \mathrm{M}$ A23187 for $5 \mathrm{~min}$. Original fractions are unprocessed supernatant. The values in parentheses represent $\mathrm{LTB}_{4}$ generation by PMN incubated with a 1:3 dilution of control culture medium and then stimulated with $2.5 \mu \mathrm{M}$ A23187. Values are mean $\pm \operatorname{SEM}(n=4)$. Fraction 1, flow-through effluent; fractions $2+3$, sequential $2-\mathrm{ml}$ aqueous eluant fractions; fraction 4, 4-ml methanol eluate. activity which eluted with particles of between $M_{\mathrm{r}} 1,300$ and $10,000 \mathrm{D}$. In each of these subjects the peak of activity was reduced by $>90 \%$ in the samples derived from PBMC which were cultured in the presence of $10^{-8} \mathrm{M}$ hydrocortisone as compared to PBMC samples cultured in the absence of corticosteroids.

In $C R$ asthmatic subjects, enhancing activity was present in all the groups of eluant fractions tested and, similarly to the CS asthmatic individuals, the major peak of activity eluted with particles of between $M_{\mathrm{r}} 1,300$ and 10,000 D. However, unlike the samples from CS asthmatic subjects, none of the peaks of activity eluting from the column were suppressed by culturing the PBMC in the presence of hydrocortisone.

The eluant fractions 24-28 after TSK 3000 HPLC of samples derived from PBMC, which were isolated from three $C R$ asthmatic subjects and then cultured in the absence of hydrocortisone, were combined and then chromatofocused on a PBE column with a pH gradient of 9-6. Enhancing activity focused between $\mathrm{pH} 6.5$ and 7.3 , with a major peak of activity eluting at $\mathrm{pH} 7.1$ and a smaller activity peak eluting at $\mathrm{pH} 6.7$ (Fig. 7).

To obtain a more accurate estimate of molecular size, the fractions eluting at $\mathrm{pH} 7.1$ and containing the maximal activity after chromatofocusing were combined and applied to a Sephadex G-50 column (Fig. 8). After Sephadex G-50 chromatography there were four peaks of enhancing activity which eluted in fractions corresponding with molecular sizes of $10,000,8,000,3,000$, and $2,000 \mathrm{D}$. The activity peak which consistently occurred at $\sim 3,000 \mathrm{D}$ coeluted with the major protein peak.

Heat stability and enzyme digestion. The stability of the PBMC-derived enhancing activity, which had been partially purified by TSK 3000 HPLC, to heat degradation and enzyme digestion was assessed in five experiments (Table V). Pronase produced a mean $95 \%$ inhibition and heat denaturation produced a mean $76 \%$ inhibition of enhancing activity. Neuraminidase produced no significant inhibition of activity.

RP-HPLC analysis of enhancing activity. The fractions corresponding with the major 3,000-D peak of activity found after Sephadex G-50 gel filtration were further purified by RPHPLC on a C-18 Spherisorb-ODS column which was eluted with a gradient of $10-40 \%$ acetonitrile in water. A representative experiment is shown in Fig. 9. There was a single peak of activity after RP-HPLC, which eluted at $10 \%$ acetonitrile.

SDS PAGE. SDS PAGE of the purified 3,000-D peptide revealed a single band corresponding with an $M_{\mathrm{r}}$ of between 2,500 and 3,000 D on staining with Coomassie Blue (Fig. 10). Autoradiography of the ${ }^{125}$ I-labeled peptide after SDS-PAGE demonstrated a single band corresponding with that found on Coomassie staining (Fig. 10).

Influence of 3,000-D peptide on superoxide production by neutrophils stimulated by PMA. To ascertain whether the priming activity of the 3,000 -D peptide was specific to leukotriene generation or represented a more widespread cellular activation involving other pro-inflammatory products, the influence of the purified peptide on superoxide $\left(\mathrm{O}_{2}^{-}\right)$production by resting and stimulated PMN was evaluated in six experiments (Fig. 11). Preincubation of PMN with the peptide for $2.5 \mathrm{~min}$ did not result in increased production of $\mathrm{O}_{2}^{-}$in $\mathrm{PMN}$ subsequently exposed to buffer alone. However, PMN preincubated with the peptide and then stimulated by exposure to PMA demonstrated enhanced $\mathrm{O}_{2}^{-}$production $(P<0.05)$ com- 
CORTICOSTEROID

SENSITIVE
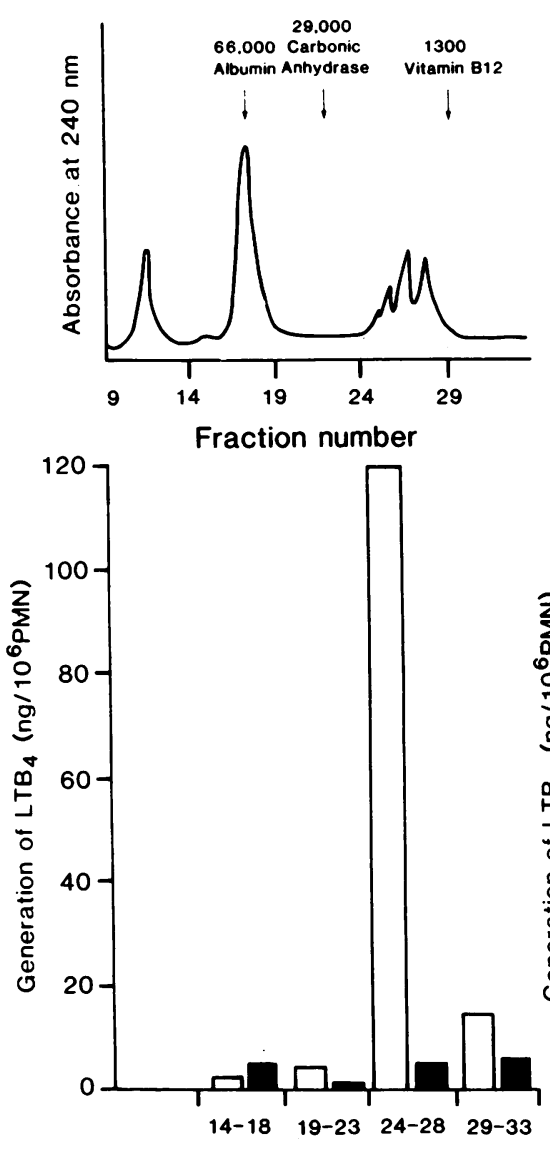

Fraction number
CORTICOSTEROID

RESISTANT
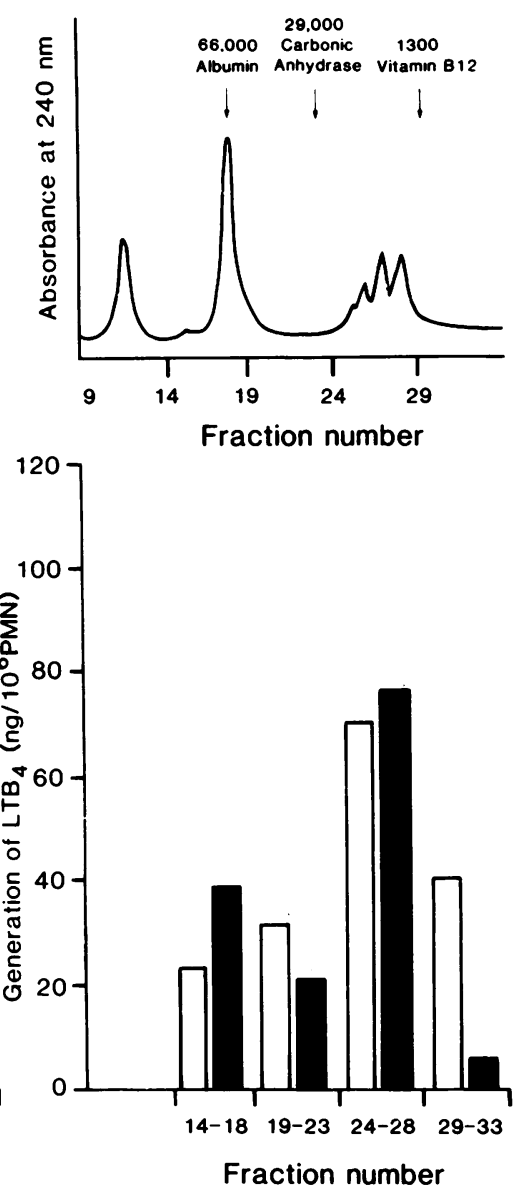

Figure 6. TSK 3000 gel filtration of PBMC culture supernatants from one CS asthmatic subject and one $\mathrm{CR}$ asthmatic subject. Column fractions were tested for enhancement of $\mathrm{LTB}_{4}$ synthesis by neutrophils (PMN) obtained from two normal donors. Open bars represent activity of supernatant derived from PBMC cultured in the absence of hydrocortisone. Shaded bars represent supernatant derived from PBMC cultured in the presence of $10^{-8}$ hydrocortisone. For each patient, the experiments with and without hydrocortisone were performed with PMN from the same donor.

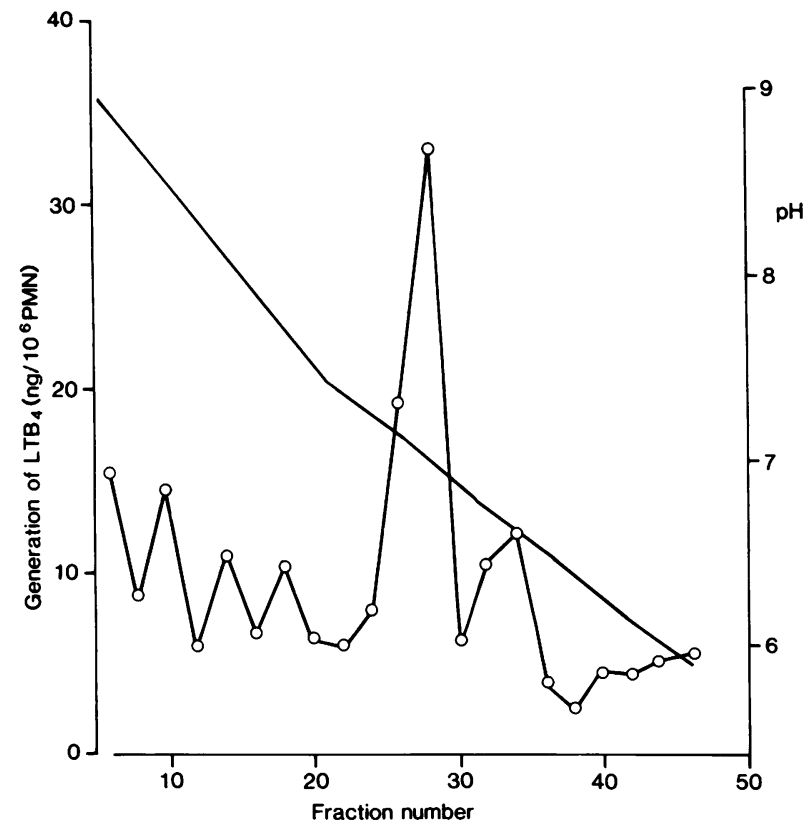

Figure 7. Chromatofocusing of PBMC culture supernatant after TSK 3000 gel filtration. Active eluant fractions from three $\mathrm{CR}$ subjects were combined before chromatofocusing. Eluate from chromatofocusing was adjusted to $\mathrm{pH} 7.4$ and then assessed for enhancement of $\mathrm{LTB}_{4}$ generation by neutrophils obtained from one normal donor.
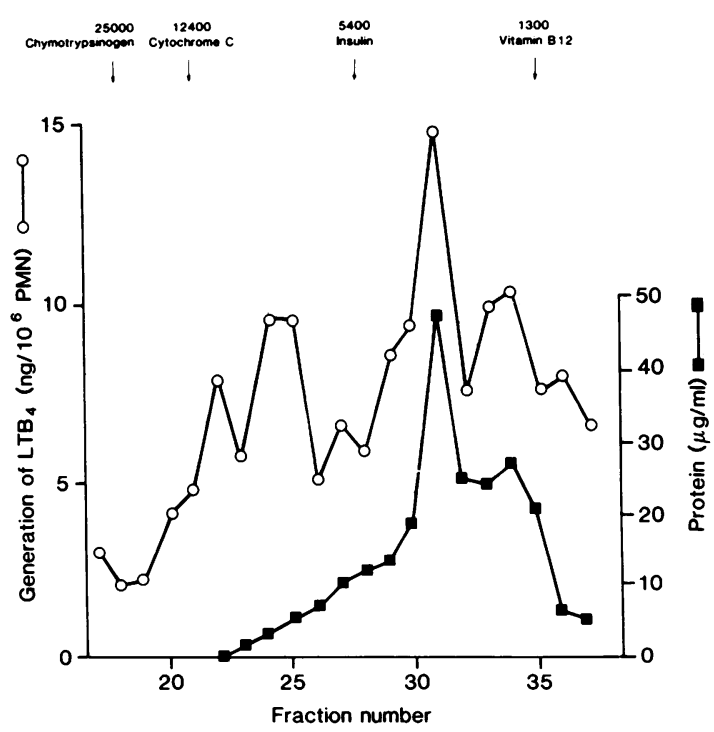

Figure 8. Sephadex G-50 gel filtration of the major peak of activity which eluted at pI 7.1 after chromatofocusing. Each point is the mean of duplicate leukotriene determinations on ionophore-activated neutrophils (PMN) obtained from one normal donor. (O) Activity peaks; and ( $\square$ ) denote protein peaks. 
Table V. Stability of PBMC-derived Enhancing Activity to Heat Treatment and Enzyme Digestion

\begin{tabular}{lcc}
\hline \multirow{2}{*}{ Treatment } & \multicolumn{2}{c}{$\mathrm{LTB}_{4}$ generation } \\
\cline { 2 - 3 } & \multicolumn{2}{c}{$n g / 10^{\circ} P M N$} \\
PBMC supernatant & Culture medium \\
None & $14.6 \pm 1.0$ & $6.4 \pm 0.4$ \\
Pronase & $6.8 \pm 1.7$ & $7.4 \pm 0.3$ \\
Neuraminidase & $12.4 \pm 2.4$ & $6.5 \pm 0.4$ \\
Heat $\left(60^{\circ} \mathrm{C}, 1 \mathrm{~h}\right)$ & $8.4 \pm 2.2$ & $6.8 \pm 0.4$ \\
\hline
\end{tabular}

Cytokine partially purified by Sep-Pak C-18 fractionation and TSK 3000 HPLC from five asthmatic subjects was concentrated 10 -fold and was then treated with pronase for $15 \mathrm{~min}$ at $37^{\circ} \mathrm{C}$, with neuraminidase for $1 \mathrm{~h}$ at $37^{\circ} \mathrm{C}$, or heated to $60^{\circ} \mathrm{C}$ for $1 \mathrm{~h}$. Samples were then diluted 1:30 and tested for enhancing activity in PMN obtained from two normal donors. PMN were preincubated with the treated cytokine for $2.5 \mathrm{~min}$ and then stimulated with $2.5 \mu \mathrm{M}$ A23187 for 5 min. The values are mean \pm SEM of five experiments.

pared with cells preincubated with buffer only and then stimulated with PMA. The enhancement was only evident with submaximal stimulation.

\section{Discussion}

We have demonstrated that the supernatants of cultures of PBMC derived from asthmatic patients prepared PMN for

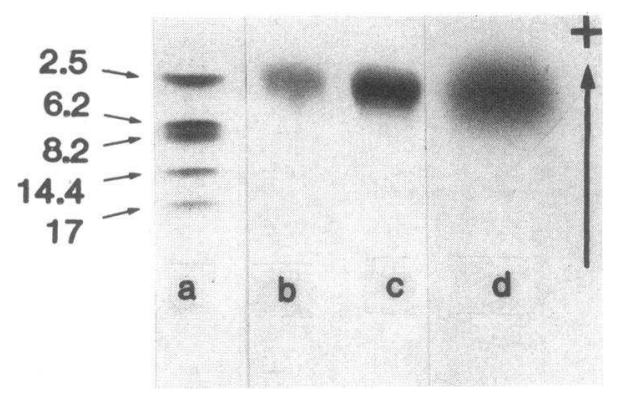

Figure 10. SDS-PAGE of the 3,000-D factor after RP-HPLC resolution. ${ }^{125}$ I-labeled samples were subjected to electrophoresis on a $20 \%$ acrylamide/SDS flat bed gel. Gels were fixed, dried, autoradiographed, and then stained with Coomassie blue. Molecular mass standards given in kilodaltons: track $a$, low molecular mass standards (Sigma Chemical Co.); track $b, 3,000$-D factor (60 ng); track $c, 3,000$ $\mathrm{D}$ factor $(600 \mathrm{ng})$; track $d$, autoradiograph of ${ }^{125}$ I-labeled factor $(600$ ng).

enhanced $\mathrm{LTB}_{4}$ generation in response to activation by the calcium ionophore A23187. The short duration for the incubation period that produced maximal enhancement suggests that protein synthesis was not required for the effect. Prolonging the incubation period from 2.5 to 10 min reduced the enhancement of $\mathrm{LTB}_{4}$ generation and release by $\mathrm{PMN}$ as previously described for stimulation of the PMN respiratory burst by formylmethionylleucylphenylalanine (FMLP) (27-29) and

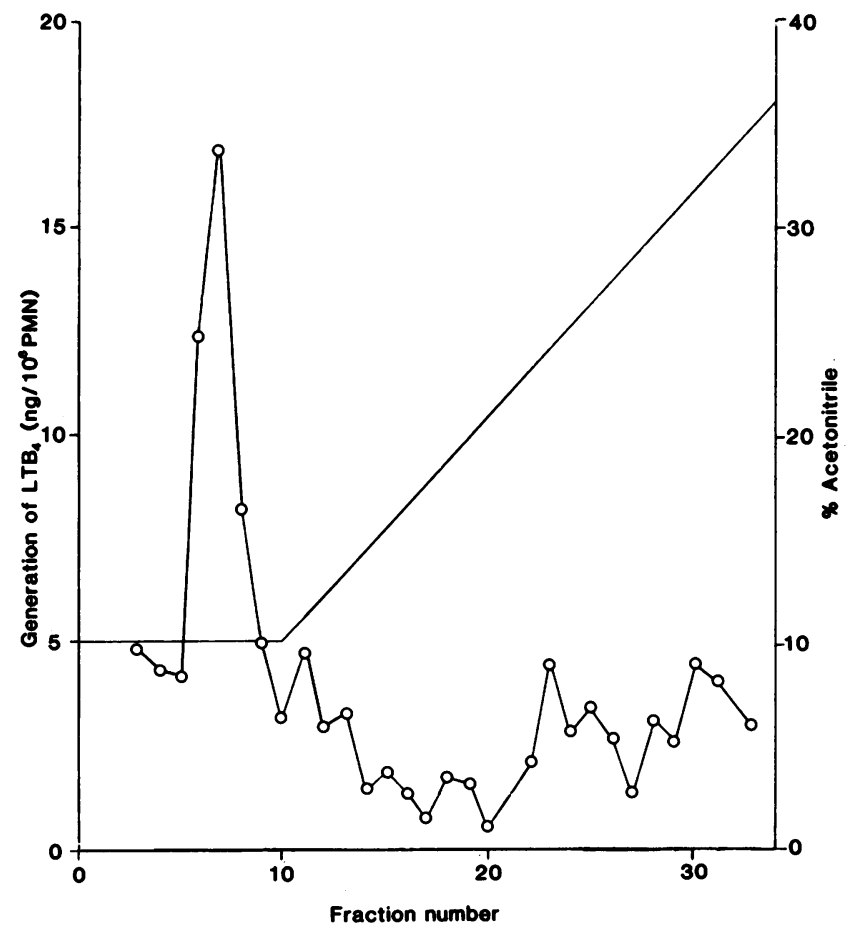

Figure 9. RP-HPLC resolution of the 3,000-D peak of enhancing activity from Sephadex G-50 gel filtration chromatography. Fractions were lyophilized, resuspended in $\mathrm{HBSS}^{++}$, and assessed for enhancement of $\mathrm{LTB}_{4}$ synthesis by neutrophils (PMN) obtained from one normal donor.

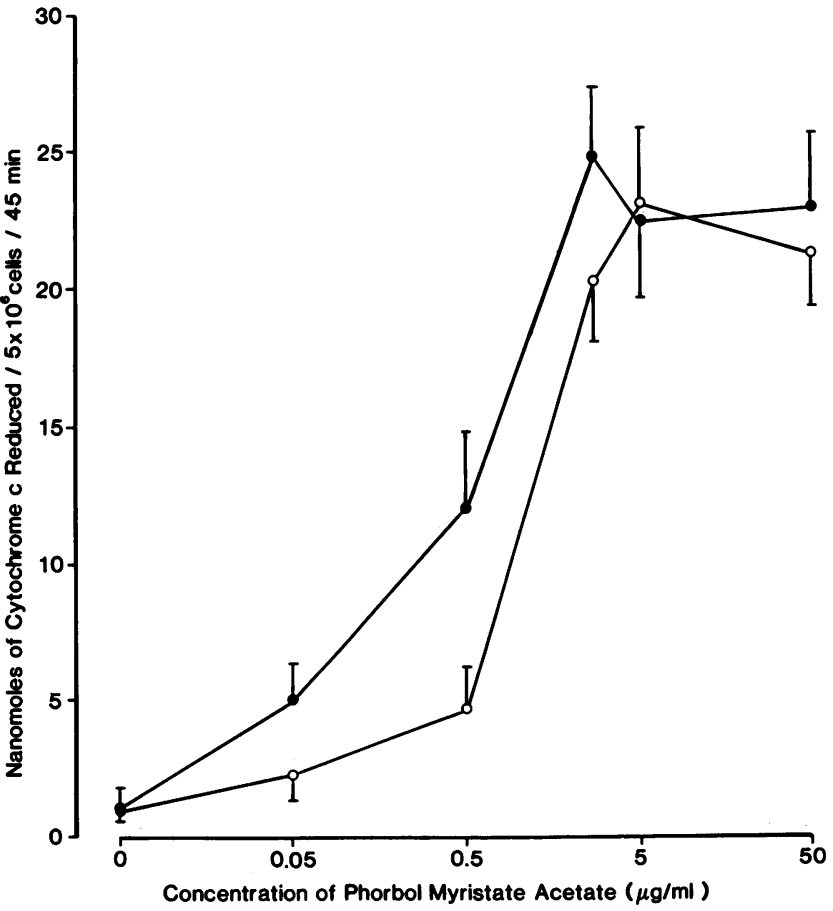

Figure 11. Production of superoxide anion (expressed as nanomoles of cytochromes reduced) by neutrophils preincubated for $2.5 \mathrm{~min}$ with either control buffer (o) or a 1:3 dilution of cytokine purified by TSK 3000 HPLC, chromatofocusing, Sephadex G50, and RP-HPLC $(\bullet)$ and then stimulated with incremental concentrations of PMA for $45 \mathrm{~min}$. Values are mean \pm SEM for six separate experiments. Six normal subjects served as donors for PMN. 
for the enhancement of PMN LTB 4 generation by a group of monocyte-derived molecules (4).

The enhancing effect of the asthmatic PBMC supernatants on $\mathrm{PMN} \mathrm{LTB}_{4}$ generation was significantly greater than that of PBMC supernatants from normal individuals, suggesting that asthmatic PBMC may already have been activated in vivo. Analysis of $\omega$-oxidation metabolites of $\mathrm{LTB}_{4}$ suggests that the apparent difference in the enhancement of $\mathrm{LTB}_{4}$ generation is at the level of biosynthesis rather than due to reduced $\omega$ metabolism of generated $\mathrm{LTB}_{4}$. Authenticity of the immunoreactive $\mathrm{LTB}_{4}$ was confirmed by subjecting the immunoreactive material to RP-HPLC and assessment of the fractional eluates by a specific $\mathrm{LTB}_{4}$ radioimmunoassay. There was only one peak of immunoreactive material which eluted at the retention time of the synthetic standard.

The enhancing activity was produced by adherent blood mononuclear cells that resisted complement-dependent lysis by anti-CD5 and anti-human Ig and were sensitive to treatment with anti-CD 14 and complement. The cells were therefore presumably monocytes. In the presence of increasing concentrations of hydrocortisone, there was a significant suppression of the production of enhancing activity from the PBMC derived from CS asthmatic subjects but not from the cells derived from the $\mathrm{CR}$ asthmatic individuals. The release of enhancing activity by PBMC was suppressed by $10^{-10}$ to $10^{-4}$ $\mathrm{M}$ hydrocortisone. The $K_{\mathrm{d}}$ of a specific glucocorticoid receptor in monocytes and macrophages ranges from 2 to $10 \mathrm{nM}$ prednisolone and from 10 to $80 \mathrm{nM}$ hydrocortisone (30-32). Glucocorticoids at comparable concentrations have previously been shown to suppress a number of mononuclear cell functions including generation of thromboxane $\mathrm{B}_{2}, \mathrm{LTB}_{4}$, and $\mathrm{LTC}_{4}(33,34)$; Ia expression and IL-1 generation by macrophages (35); and IL-1 generation (36) and colony formation (3) by monocytes. The dose which produced $50 \%$ inhibition $\left(\mathrm{ID}_{50}\right)$ for such suppressive effects range from $\sim 5 \times 10^{-8} \mathrm{M}$ hydrocortisone for leukotriene generation to $10^{-6} \mathrm{M}$ for arachidonic acid release (37). Paradoxical stimulatory effects of low concentrations of glucocorticoids on mediator release have been reported (34), but suppressive effects at concentrations lower than $10^{-8} \mathrm{M}$ have not previously been described. The low effective concentrations of hydrocortisone observed in this study suggest that either the mechanism involved in the inhibitory effect does not require a high degree of binding to the glucocorticoid receptor, or that the response is mediated via a high-affinity receptor.

The PBMC from CR subjects were resistant to the suppressive effects of hydrocortisone at concentrations which were similar to those achieved clinically in the treatment of acute asthma (38). There was no difference between the CS asthmatic subjects and the $C R$ asthmatic subjects in the time interval between isolation of the PBMC for the in vitro experiments and the last ingestion of corticosteroid therapy. Thus, the response of each individual group of patients was not influenced by the administration of exogenous corticosteroid. The significant positive correlation between the suppression of priming activity by hydrocortisone in vitro and the clinical improvement in $\mathrm{FEV}_{1}$ after treatment with prednisolone suggests that the cell types involved in generating the enhancing activity may be similar to those contributing to the pathogenesis of asthma in these patients.

In view of the potential importance of a molecule which could enhance the pro-inflammatory functions of granulo- cytes which was not suppressed by corticosteroids, we elected to focus on the characterization of the activity produced by PBMC of CR asthmatic subjects. Thus, the major peak of activity eluting from the TSK 3,000 HPLC column was sequentially purified by chromatofocusing, gel filtration, and RP-HPLC. After chromatofocusing, there was one major peak of activity which eluted with an estimated pI of 7.1. When this peak of activity was subjected to gel filtration chromatography on columns of Sephadex G-50 it eluted in four peaks of activity with estimated molecular sizes of between 12,400 and $2,000 \mathrm{D}$. This is equally compatible with several distinct and unrelated molecules carrying the activity, as with a family of molecules related as aggregates or cleavage products. When the major peak of activity which coeluted with the major protein peak from Sephadex G-50 in fractions corresponding with an $M_{\mathrm{r}}$ of 3,000 D, was subjected to further purification by RPHPLC (39), there was only one peak of activity and this eluted prior to the start of the linear acetonitrile gradient. SDS-PAGE of this material demonstrated a single protein band both on autoradiography and on staining with Coomassie Blue. The finding that the material was pronase and heat-sensitive, but resistant to neuraminidase, suggested that it had a peptide structure. The size and charge of the molecule suggests that it was not IL-1 (40) or interferon- $\alpha$ (41), both of which have been reported to modulate prostaglandin biosynthesis in fibroblasts and macrophages (42), or granulocyte/macrophage colony-stimulating factor and tumor necrosis factor which increase leukotriene biosynthesis in neutrophils and eosinophils $(43,44)$.

To evaluate whether the enhancing activity of the 3,000-D molecule was selective for leukotriene generation, or represented a more widespread cellular activation, the capacity of the molecule to enhance generation of superoxide anion by PMN subsequently stimulated with PMA was assessed. The purified molecule also enhanced superoxide generation by PMA stimulated PMN, but did not stimulate superoxide generation in the absence of PMA (Fig. 11).

A substantial body of evidence implicates cells of the monocyte lineage in the mechanisms of asthma (2, 3, 45-49). There are several ways in which improvement in the clinical condition of asthmatic patients treated with corticosteroids may depend upon the effects of these drugs on such cells. There is well-documented inhibition of production of cytokines by low concentrations of corticosteroids $(3,35,36)$, and inhibition of arachidonic acid release in leukocytes $(33,34$, 37). Our results, therefore, would support the view that cells of monocyte lineage within the lungs of $C R$ asthmatic patients enhance the pro-inflammatory potential of infiltrating PMN and that they exist in a hyperreactive state with increased cytokine production despite the presence of inhibitory concentrations of corticosteroids.

We have studied corticosteroid resistance in chronic asthma by selecting patients of two polar extremes on the basis of their clinical response to corticosteroid treatment. It is likely, however, that corticosteroid sensitivity and resistance forms a continuous spectrum (3). It is, nevertheless, critical to recognize patients whose asthma is highly resistant to systemic corticosteroids, since these individuals may otherwise be needlessly exposed to high doses of corticosteroid treatment with little or no benefit. This study indicates one way in which such patients may be identified. The mechanism of the cellular basis of corticosteroid resistance remains unknown. A success- 
ful definition of the mechanism(s) will allow further understanding of not only corticosteroid resistance, but also the manner in which corticosteroids function in asthma.

\section{Acknowledgments}

This work was supported in part by the Chest, Heart and Stroke Association, Wellcome Trust, and the Asthma Research Council, UK. The $\mathrm{LTB}_{4}$ antiserum was a gift from Dr. A. W. Ford-Hutchinson, Merck Frosst.

\section{References}

1. Carmichael, J., I. C. Paterson, P. Diaz, G. K. Crompton, A. B. Kay, and I. W. B. Grant. 1981. Corticosteroid resistance in chronic asthma. Br. Med. J. 282:1419-1422.

2. Kay, A. B., P. Diaz, J. Carmichael, and I. W. B. Grant. 1981. Corticosteroid-resistant chronic asthma and monocyte complement receptors. Clin. Exp. Immunol. 44:576-580.

3. Poznansky, M. C., A. C. H. Gordon, J. G. Douglas, A. S. Krajewski, A. H. Wyllie, and I. W. B. Grant. 1984. Resistance to methylprednisolone in cultures of blood mononuclear cells from glucocorticoid-resistant asthmatic patients. Clin. Sci. (Lond.). 67:639-645.

4. Dessein, A. J., T. H. Lee, P. Elsas, J. Ravalese III, D. Silverstein, J. R. David, K. F. Austen, and R. A. Lewis. 1986. Enhancement by monokines of leukotriene generation by human eosinophils and neutrophils stimulated with calcium ionophore A23187. J. Immunol. 136:3829-3838.

5. Shaw, R. J., G. M. Walsh, O. Cromwell, R. Moqbel, C. J. F. Spry, and A. B. Kay. 1985. Activated human eosinophils generate SRS-A leukotrienes following IgG-dependent stimulation. Nature (Lond.). 316:150-152.

6. Samuelsson, B. 1983. Leukotrienes: mediators of immediate hypersensitivity reactions and inflammation. Science (Wash. DC). 220:568-575.

7. Lewis, R. A., and K. F. Austen. 1984. The biologically active leukotrienes: biosynthesis, metabolism, receptors, functions and pharmacology. J. Clin. Invest. 73:889-897.

8. Ford-Hutchinson, A. W., M. A. Bray, M. V. Doig, M. E. Shipley, and M. J. H. Smith. 1980. Leukotriene B: a potent chemokinetic and aggregating substance released from polymorphonuclear leukocytes. Nature 286:264-265.

9. Goetzl, E. J., and W. C. Picket. 1981. Novel structural determinants of the human neutrophil chemotactic activity of leukotriene $\mathbf{B}_{\mathbf{4}}$. J. Exp. Med. 153:482-487.

10. Nagy, L., T. H. Lee, E. J. Goetzl, W. C. Pickett, and A. B. Kay. 1982. Complement receptor enhancement and chemotaxis of human neutrophils and eisonophils by leukotrienes and other lipoxygenase products. Clin. Exp. Immunol. 47:541-547.

11. Palmer, R. M., R. J. Stepney, G. Higgs, and K. E. Eakins. 1980. Chemokinetic activity of arachidonic acid lipoxygenase products on leukocytes of different species. Prostaglandins. 20:411-418.

12. Drazen, J. M., K. F. Austen, R. A. Lewis, D. A. Clark, G. Toto, A. Marfat, and E. J. Corey. 1980. Comparative airway and vascular activities of leukotrienes $\mathrm{C} 1$ and $\mathrm{D}$ in vivo and in vitro. Proc. Natl. Acad. Sci. USA. 77:4354-4358.

13. Lewis, R. A., J. M. Drazen, K. F. Austen, D. A. Clark, and E. J. Corey. 1980. Identification of the C(6)-S-conjugate of leukotriene A with cysteine as a naturally occurring, slow reacting substance of anaphylaxis (SRS-A): importance of the 11-cis geometry of biological activity. Biochem. Biophys. Res. Commun. 96:271-277.

14. Peck, M. J., P. J. Piper, and T. J. Williams. 1981. The effects of leukotrienes $\mathrm{C}_{4}$ and $\mathrm{D}_{4}$ on the microvasculature of guinea pig skin. Prostaglandins. 21:315-321.

15. Dahlen, S. E., J. Bjork, P. Hedgvist, K. E. Arfors, S. Hammarstrom, J. A. Lindgren, and B. Samuelsson. 1981. Leukotrienes promote plasma leakage and leukocyte adhesion in post-capillary venules: in vivo effects with relevance to the acute inflammatory response. Proc. Natl. Acad. Sci. USA. 78:3887-3891.

16. Arm, J. P., B. Spur, and T. H. Lee. 1988. The effects of inhaled leukotriene $\mathrm{E}_{4}$ on the airways responsiveness to histamine in subjects with asthma and normal subjects. J. Allergy Clin. Immunol. 82:654660 .

17. Boyum, A. 1968. Ficoll-Hypaque method of separating mononuclear cells and granulocytes from human blood. Scand. J. Clin. Lab. Invest. 21(Suppl. 97):77-89.

18. Vadas, M. A., J. R. David, A. E. Butterworth, N. T. Pisani, and T. A. Siongok. 1979. A new method for the purification of human eosinophils and a comparison of the ability of these cells to damage schistosomula of Schistosoma mansoni. J. Immunol. 122:1228-1236.

19. Lewis, R. A., J-M. Mencia-Huerta, R. J. Soberman, D. Hoover, A. Marfat, E. J. Corey, and K. F. Austen. 1982. Radioimmunoassay for leukotriene $\mathrm{B}_{4}$. Proc. Natl. Acad. Sci. USA. 79:7904-7908.

20. Rokach, J., E. C. Hayes, Y. Girard, D. L. Lombardo, A. L. Maycock, A. S. Rosenthal, R. N. Young, R. Zamboni, and H. J. Zweerink. 1984. The development of sensitive and specific radioimmunoassays for leukotrienes. Prostaglandins Leukotrienes Med. 13:21-25.

21. Kaplow, L. S. 1979. Simplified myeloperoxidase stain using benzidine dihydrochloride. Blood. 26:215-219.

22. Sluyterman, L. A. A., and J. Wijdenes. 1977. Chromatofocusing: isoelectric focusing on ion exchangers in the absence of an externally applied potential. In Proceedings of the International Symposium on Electrofocusing and Isotachophoresis. B. J. Radola, and D. Graesslin, editors. Walter de Gruyter, Berlin. 463-466.

23. Sluyterman, L. A. A., and O. Elgersma. 1978. Chromatofocusing: isoelectric focusing on ion exchange columns. I. General principles. J. Chromatogr. 150:17-30.

24. Sluyterman, L. A. A., and J. Wijdenes. 1978. Chromatofocusing: isoelectric focusing on ion exchange columns. II. Experimental verification. J. Chromatogr. 150:31-44.

25. Bolton, A. E., and W. M. Hunter. 1973. The labelling of proteins to high specific radioactivities by conjugation to a ${ }^{125}$ I-containing acylating agent. Biochem. J. 133:529-539.

26. Babior, B. M., R. S. Kipnes, and J. T. Curnutte. 1973. Biological defense mechanisms: the production by leukocytes of superoxide, a potential bactericidal agent. J. Clin. Invest. 52:741-744.

27. Bender, J. G., L. C. McPhail, and D. E. Van Epps. 1983. Exposure of human neutrophils to chemotactic factors potentiates activation of the respiratory burst enzyme. J. Immunol. 130:2316-2323.

28. McPhail, L. C., C. C. Clayton, and R. Snyderman. 1984. The NADPH oxidase of human polymorphonuclear leukocytes: evidence for regulation by multiple signals. J. Biol. Chem. 259:5768-5775.

29. English, D., J. S. Roloff, and N. J. Lukens. 1981. Chemotactic factor enhancement of superoxide release from fluoride and phorbol myristate acetate stimulated neutrophils. Blood. 58:129-134.

30. Lippman, M., and R. Barr. 1977. Glucocorticoid receptors in subpopulations of lymphocytes. J. Immunol. 118:1977-1981.

31. Werb, Z., R. Foley, and A. Munck. 1978. Interactions of glucocorticoids with monocytes and macrophages: identification of glucocorticoid receptors in monocytes and macrophages. J. Exp. Med. 147:1684-1694.

32. Ozaki, T., S. Yasuoka, T. Nakayama, and E. Tsubura. 1982. Glucocorticoid receptors in human alveolar macrophages and peripheral blood cells. Clin. Exp. Immunol. 47:505-511.

33. Fuller, R. W., C. R. Kelsey, P. J. Cole, C. T. Dollery, and J. MacDermot. 1984. Dexamethasone inhibits the production of thromboxane $B_{2}$ and leukotriene $B_{4}$ by human alveolar and peritoneal macrophages in culture. Clin. Sci. (Lond.). 67:653-656.

34. Peters-Godden, M., and P. Thebert. 1987. Inhibition by methylprednisolone of zymosan-induced leukotriene synthesis in alveolar macrophages. Am. Rev. Respir. Dis. 130:803-809.

35. Snyder, D. S., and E. R. Uranue. 1982. Corticosteroids inhibit murine macrophage Ia expression and interleukin-1 production. $J$. Immunol. 129.5. 1803-1805. 
36. Smith, K. A., L. B. Lachman, J. J. Oppenheim, and M. F. Fatava. 1980. The functional relationship of the interleukins. J. Exp. Med. 151:1551-1556.

37. Peters-Golden, M., J. Bathon, R. Flores, F. Hirata, and D. S. Newcombe. 1984. Glucocorticoid inhibition of zymosan induced arachidonic acid release by rat alveolar macrophages. Am. Rev. Respir Dis. 130:803-809.

38. Collins, J. V., T. J. H. Clark, P. W. R. Harris, and J. Townsend 1970. Intravenous corticosteroids in treatment of acute bronchial asthma. Lancet. 2:1047-1049.

39. Schroder, J.-M., U. Mrowietz, and E. Christophers. 1988. Purification and partial biologic characterization of a human lymphocytederived peptide with potent neutrophil-stimulating activity. J. Immunol. 140:3534-3540.

40. Kronheim, S. R., C. J. March, S. K. Erb, P. J. Conlon, D. Y. Mochizuki, and T. P. Hopp. 1985. Human interleukin-1: purification to homogeneity. J. Exp. Med. 161:490-502.

41. Yip, Y. K., R. H. L. Pang, C. Ruban, and J. Vilcek. 1981. Partial purification and characterization of human (immune) interferon. Proc. Natl. Acad. Sci. USA. 78:1601-1605.

42. Yaron, M., J. Yaron, D. Gurari-Rotman, M. Revel, H. R. Lindner, and U. Zor. 1977. Stimulation of prostaglandin E production in cultured human fibroblasts by poly (I) poly (C) and human interferon. Nature. 267:457-459.

43. Dahinden, C. A., J. Zingg, F. E. Maly, and A. L. de Weck. 1988. Leukotriene production in human neutrophils primed by recombinant granulocyte/macrophage colony-stimulating factor and stimulated with the complement component C5a and FMLP as second signals. $J$. Exp. Med. 167:1281-1298.

44. Roubin, R., P. P. Elsas, W. Fiers, and A. J. Dessein. 1987. Recombinant human tumour necrosis factor (TNF) enhances leukotriene biosynthesis in neutrophils and eosinophils stimulated with the $\mathrm{Ca}^{2+}$ ionophore A23187. Clin. Exp. Immunol. 70:484-490.

45. Damon, M., C. Chavis, A. Crastes de Paulet, F. B. Michel, and P. L. Godard. 1987. Arachidonic acid metabolism in alveolar macrophages: a comparison of cells from healthy subjects, allergic asthmatics and chronic bronchitis patients. Prostaglandins. 34:291-309.

46. Joseph M., A. B. Tonnel, G. Torpier, A. Capron, B. Arnoux, and J. Benveniste. 1983. Involvement of IgE in the secretory processes of alveolar macrophages from asthmatic patients. J. Clin. Invest. 71:222-230.

47. Rankin, J. A., M. Hitchcock, W. W. Merrill, M. K. Bach, J. R. Brashar, and P. W. Askenase. 1982. IgE-dependent release of leukotriene $\mathrm{C}_{4}$ from alveolar macrophages. Nature (Lond.). 279, 329-331.

48. Arnoux, B., E. Jouvin Marche, A. Arnoux, and J. Benveniste. 1982. Release of PAF-acether from human blood monocytes. Agents Actions. 12:713-716.

49. Gosset, P., A. B. Tonnel, M. Joseph, L. Prin, A. Mallart, J. Charon, and A. Capron. 1984. Secretion of a chemotactic factor for neutrophils and eosinophils by alveolar macrophages from asthmatic patients. J. Allergy Clin. Immun. 74:827-834. 